\title{
Pengelolaan Keuangan Sarana Dan Prasarana Pengembangan Desa Wisata Di Desa Banjarsari Kecamatan Manyar Kabupaten Gresik
}

\author{
Siti Samsiyah ${ }^{1}$, Tri Ariprabowo ${ }^{2}$, Fachrudy Asj'ari ${ }^{3}$,Bisma Arianto ${ }^{4}$, Fauziyah ${ }^{5}$ \\ 1,2,3,4 Program Studi Manajamen, Fakultas Ekonomi, Universitas PGRI Adi Buana Surabaya \\ ${ }^{4}$ Program Studi Akuntansi, Fakultas Ekonomi, Universitas PGRI Adi Buana Surabaya \\ Email :sam.si29@yahoo.co.id
}

\begin{abstract}
ABSTRAK
Tujuan kegiatan pengabdian kepada masyarakat ini adalah untuk menambah wawasan serta memberikan pengetahuan usaha dan pengembangan desa Banjarsari. Sedangkan produk unggulan yang ingin dikembangkan di Desa Banjarsari Kecamatan Manyar Kabupaten Gresik ini adalah desa wisata. Desa Banjarsari merupakan desa yang mempunyai lahan luas untuk pengembangan desa wisata dan untuk meningkatkan sektor perekonomian masyarakat desa Banjarsari. Namun dalam pengelolaan keuangan, sarana dan prasarana wisata Desa Banjarsari perlu memiliki strategi yang kuat, agar pengeluaran tidak melebihi pendapatan sehingga diharapkan perekonomian masyarakat desa Banjarsari dapat meningkat dan menambah kreativitas, motivasi dan inovasi yang lebih baik. Pembangunan suatu objek wisata harus dirancang dengan bersumber pada potensi daya tarik yang memiliki objek tersebut dengan mengacu pada kriteria keberhasilan pengembangan yang meliputi berbagai kelayakan. Perencanaan pembangunan pariwisata pedesaan merupakan bentuk integrasi antara atraksi, akomodasi dan fasilitas yang disajikan dalam suatu struktur kehidupan masyarakat yang menyatu dengan tradisi setempat.
\end{abstract}

Kata Kunci : Pengelolaan Keuangan, Sarana dan Prsarana, Desa Wisata

\section{ABSTRACT}

The purpose of this community service activity is to add insight and provide business knowledge and development of the Banjarsari village. Meanwhile, the superior product that wants to be developed in Banjarsari Village, Manyar District, Gresik Regency is a tourist village. Banjarsari Village is a village that has a large area of land for the development of a tourist village and to improve the economic sector of the Banjarsari village community. However, in financial management, tourism facilities and infrastructure for Banjarsari Village need to have a strong strategy, so that expenses do not exceed income so that it is hoped that the economy of the Banjarsari Village community can increase and increase creativity, motivation and better innovation. The construction of a tourist object must be designed based on the potential attraction that the object has with reference to the development success criteria which includes various feasibility. Rural tourism development planning is a form of integration between attractions, accommodation and facilities that are presented in a structure of community life that integrates with local traditions.

Keywords: Financial Management, Facilities and Facilities 


\section{PENDAHULUAN}

Kecamatan Manyar adalah Kecamatan yang terletak dibagian Kabupaten Gresik, Propinsi Jawa Timur. Secara geografis sebagian besar wilayahnya adalah berupa lahan tambak, karena posisinya yang dekat dengan pantai. Seiring perkembangan zaman kawasan ini sekarang mulai tumbuh berbagai macam industri kecil menengah sampai yang berskala Nasional maupun Internasional. Kecamatan Manyar memiliki luas wilayah sebesar 9.542,49 ha, terdiri dari 23 desa. Desa terkecil luasannya adalah Desa Ngampel dengan luas $0.76 \mathrm{~km} 2$ ha dan desa terluas adalah Desa Leran dengan luas $12.67 \mathrm{~km} 2$. Sedangkan desa Banjarsari tanahnya 2.67 ha, luasnya berada ditengah-tengah dari kecamatan Manyar. Berdasarkan perbedaan tingkat ketinggian daerah di Kecamatan Manyar sebagian besar secara keseluruhan merupakan dataran rendah dan sedang. Curah hujan disuatu tempat antara lain di pengaruhi oleh keadaan iklim, keadaan kelembaban udara, serta perputaran / pertemuan arus udara. Oleh karena itu jumlah curah hujan setiap daerah selalu beragam dari bulan kebulan. Keadaan cuaca ini banyak mempengaruhi semua kegiatan pembangunan, baik yang berhubungan langsung dengan kegiatan yang bersangkutan dengan wadah pembangunan itu sendiri yang berupa tanah. Curah hujan adalah $1.227 \mathrm{~mm}$, dengan rata-rata perhari adalah $20.45 \mathrm{~mm}$, dan jumlah hari hujan adlah 60 hari. Jumlah penduduk di Kecamatan Manyar tahun 2014 sebesar 110.731 jiwa dengan komposisi penduduk laki-laki adalah 56.275 jiwa dan penduduk perempuan 54.456 jiwa. Rata rata kepadatan penduduk di kecamatan Manyar adalah 1.160 jiwa / km2 dengan jumlah 4 jiwa/ rumah tangga. Jenis penggunaan tanah di Kecamatan Manyar meliputi : Tanah Sawah sebesar 356.21 ha; Tanah tambak 5.833,11 Ha, Tanah Kering sebesar 962.30 Ha, ; Bang/Pekarangan sebesar 1.257,05 Ha dan Lain-lain sebesar 1.1133,82 ha. Salah satu desa yang ikut berperan memajukan kecamatan Manyar adalah Desa Banjarsari dari total 23 desa (Kabupaten Gresik, 2019).

Produk unggulan dari desa ini adalah Wisata, usaha tersebut merupakan usaha yang dilakukan untuk meningkatkan sektor pengembangan di Desa Banjarsari. Namun dalam pengelolaan keuangan, sarana dan prasarana wisata Desa Banjarsari perlu memiliki strategi agar pengeluaran tidak melebihi pendapatan sehingga diharapkan perekonomian masyarakat desa Banjarsari dapat meningkat. dan menambahkan inovasi dan motivasi yang lebih baik lagi. Pembangunan suatu objek wisata harus dirancang dengan bersumber pada potensi daya tarik yang memiliki objek tersebut dengan mengacu pada kriteria keberhasilan pengembangan yang meliputi berbagai kelayakan. Daerah Tujuan Wisata Sesuai dengan Undang-Undang Republik Indonesia No. 10 Tahun 2009 tentang kepariwisataan, menjelaskan beberapa pengertian istilah kepariwisataan, antara lain:

1. Wisata adalah suatu kegiatan perjalanan yang dilakukan oleh individu atau kelompok mengunjungi suatu tempat dan bertujuan untuk rekreasi, pengembangan pribadi, atau untuk mempelajari keunikan daya tarik suatu tempat wisata yang dikunjungi dalam waktu sementara.

2. Pariwisata yang didukung oleh berbagai layanan fasilitas yang disediakan masyarakat, pengusaha, dan pemerintah daerah. 
3. Daerah tujuan wisata dapat disebut juga dengan destinasi pariwisata merupakan kawasan geografis yang berada dalam satu atau lebih wilayah administrasi yang di dalamnya terdapat daya tarik wisata, fasilitas umum, fasilitas pariwisata, aksesbilitas, serta masyarakat yang saling terkait dan melengkapi terwujudnya kepariwisataan.

Pitana, I. Gede dan Gayatri, Putu G. (2005) mengemukakan bahwa suatu daerah tujuan wisata (destinasi wisata) adalah sebuah susunan sistematis dari tiga elemen. Seorang dengan kebutuhan wisata adalah inti/pangkal (keistimewaan apa saja atau karekteristik suatu tempat yang akan mereka kunjungi) dan sedikitnya satu penanda (inti informasi). Seseorang melakukan perjalanan wisata dipengaruhi oleh faktor-faktor yang menjadi daya tarik yang membuat seseorang rela melakukan perjalanan yang jauh dan menghabiskan dana cukup besar. Suatu daerah harus memiliki potensi daya tarik yang besar agar para wisatawan mau menjadikan tempat tersebut sebagai destinasi wisata.

Menurut Janianton Damanik dkk (2019) perencanaan pembangunan pariwisata pedesaan di Indonesia adalah desa wisata merupakan bentuk integrasi antara atraksi, akomodasi dan fasilitas yang disajikan dalam suatu struktur kehidupan masyarakat yang menyatu dengan tradisi setempat. Terminologi desa wisata (tourism Village) jarang ditemukan di dalam literature. Para ahli mengakui kebingungan mengartikannya dengan mengaitkan sejumlah aktivitas pariwisata yang berkembang di daerah pedesaan (Parekh, 2010). Rural tourism adalah bentuk alternative pariwisata yang mampu menyumbang perubahan-perubahan positif terhadap sumberdaya social, ekonomi dan budaya di daerah pedesaan. Pembangunan prasarana wisata yang mempertimbangkan kondisi dan lokasi akan meningkatkan aksesbilitas suatu objek wisata yang pada gilirannya akan dapat meningkatkan daya tarik objek wisata itu sendiri. Di samping berbagai kebutuhan yang telah disebutkan di atas, kebutuhan wisatawan yang lain juga perlu disediakan di daerah tujuan wisata seperti bank, apotik, rumah sakit, pom bensin, pusat-pusat pembelanjaan dan sebagainya.

Dalam melaksanakan pembangunan prasarana wisata diperlakukan koordinasi yang mantang antara instansi terkait bersama dengan instalasi pariwisata di berbagai tingkatan. Dukungan instansi terkait dalam membangun prasarana wisata sangat diperlukan bagi pengembangan pariwisata di daerah. Koordinasi di tingkat perencanaan yang dilanjutkan dengan koordinasi di tingkat pelaksanaan merupakan modal utama suksesnya pembangunan periwisata. Dalam pembangunan prasarana pariwisata pemerintah lebih dominan karena pemerintah dapat mengambil manfaat ganda dari pembangunan tersebut, seperti untuk meningkatkan arus informasi, arus lalu lintas ekonomi, arus mobilitas manusia antara daerah dan sebagainya yang tentu saja dapat meningkatkan kesempatan berusaha dan bekerja. Yang dimaksud dengan sarana dan prasarana adalah semua fasilitas yang memungkinkan proses perekonomian, dalam hal ini adalah sektor pariwisata dapat berjalan dengan lancar sedemikian rupa, sehingga dapat memudahkan manusia untuk memenuhi kebutuhannya. Jadi fungsinya adalah melengkapi sarana kepariwisataan sehingga dapat memberikan pelayanan sebagaimana mestinya. 


\section{METODE PELAKSANAAN}

Sasaran penyuluhan atau sosialisasi pelatihan pengembangan desa wisata di desa Banjarsari Kecamatan Manyar ini bergerak dalam bidang pengelolaan keuangan sarana dan prasarana untuk pengembangan wisata di desa Banjarsari Kecamatan Manyar Kabupaten Gresik tahap awal pelaksanaan adalah sebagai berikut :

1. Lahan yang sudah tersedia.

2. Investor dan kerja sama dengan pemerintah daerah sudah dilakukan

3. Sumber daya manusia sudah disiapkan

4. Pelaksnaan menunggu surat ijin dari pemerintah.

Pengembangan desa wisata di desa Banjarsari ini diharapkan meningkatkan pertumbuhan perekonomian, dan para pengusaha kecil bisa membantu mengembangkan desanya untuk menambah ekonomi dengan harapan untuk mensejahterakan masyarakat disekitarnya.

Kegiatan pengabdian ini menjadi bagian penting dari Fakultas Ekonomi dan Bisnis Program Studi Manjemen Universitas PGRI Adi Buana Surabaya. Metode kegiatan yang dilakukan pada pengabdian ini adalah :

1. Penyusunan proposal pada tahap awal, tim ini akan melakukan rancangan kegiatan pengabdian kepada masyarakat yaitu rancangan pengelolaan keuangan pengembangan desa wisata.

2. Pelaksanaan simulasi dilakukan untuk mengetahui strategi pengelolaan sarana dan prasarana.

3. Pendampingan dilaksanakan pembangunan wisata desa dan pengembangan sumber daya manusia beserta investor yang akan menanganinya sebagai wujud pengabdian kepada masyarakat.

Untuk mengetahui terwujudnya keberhasilan pengabdian pada masyarakat, adalah apabila masyarakat desa tersebut saling kerja sama dan gotong royong untuk memajukan dan mensejahterakan masyarakat.

\section{HASIL DAN PEMBAHASAN}

Wisata desa merupakan kegiatan perjalanan yang dilakukan oleh seseorang atau kelompok orang dengan mengunjungi tempat tertentu untuk tujuan rekreasi, pengembangan pribadi, atau mempelajari keunikan daya tarik wisata yang dikunjungi dalam jangka waktu sementara. Organisasi kepariwisataan adalah institusi baik dilingkungan pemerintah maupun swasta yang berhubungan dengan penyelenggaraan kegiatan kepariwisataan.

\section{Pengelolaan keuangan}

Pengeloaan keuangan ini merupakan suatu kegiatan perencanaan, penganggaran, pemeriksaan, pengelolaan, pengendalian, pencarian dan penyimpanan dana yang dimiliki oleh suatu organisasi atau perusahaan. Desa Banjarsari Keacamatan Manyar Kabupaten Gresik merupakan desa yang mempunyai lahan yang luas untuk mengembangkan desa wisata. Dalam melaksanakan pengembangan desa wisata perlu adanya pembangunan yang didukung dengan modal, sarana dan prasarana serta pengelolaan keuangan untuk 
meningkatkan perekonomian masyarakat desa Banjarsari. Pengembangan desa wisata diperlukan koordinasi yang matang dengan instansi terkait.

\section{Sarana dan Prasaran}

Sarana dan prasarana untuk pariwisata adalah sebagai unsur yang melengkapi dan bertujuan untuk memudahkan proses kegiatan pariwisata dapat berjalan dengan lancar. Prasarana umumnya merupakan kelengkapan dasar fisik suatu lingkungan yang pengadaannya memungkinkan suatu lingkungan dapat beroperasi dan berfungsi sebagaimana mestinya. Pemberdayaan masyarakat disekitarnya merupakan upaya meningkatkan kesadaran, kapasitas, akses, dan peran masyarakat, baik secara individu maupun kelompok, dalam memajukan kualitas hidup, kemandirian, dan kesejahteraan melalui kegiatan kepariwisataan. Pembangunan adalah suatu proses perubahan ke arah yang lebih baik yang didalamnya meliputi upaya-upaya perencanaan, implementasi dan pengendalian, dalam rangka penciptaan nilai tambah sesuai yang dikehendaki.daerah tujuan pariwisata yang selanjutnya disebut destinasi pariwisata adalah kawasan geografis yang berada dalam satu atau lebih wilayah administrative yang didalamnya terdapat daya tarik wisata, aksesibilitas, serta masyarakat yang saling terkait dan melengkapi terwujudnya keapriwisataan. Oleh karena itu pengembangan wisata desa perlu adanya dukungan yang sangat kuat oleh lingkungan sekitar dan pemerintah daerah.

Untuk mengetahu terwujudnya keberhasilan pengabdian pada masyarakat, indikasinya adalah apabila dalam pengelolaan keuangan dan terpenuhinya sarana dan prasarana untuk pengembangan desa wisata yang berada di desa Banjarsari kecamatan Manyar kabupaten Gresik. Adapun dokumen pelaksanaan pengabdian pada masyarakat tertera pada gambar dibawah ini.

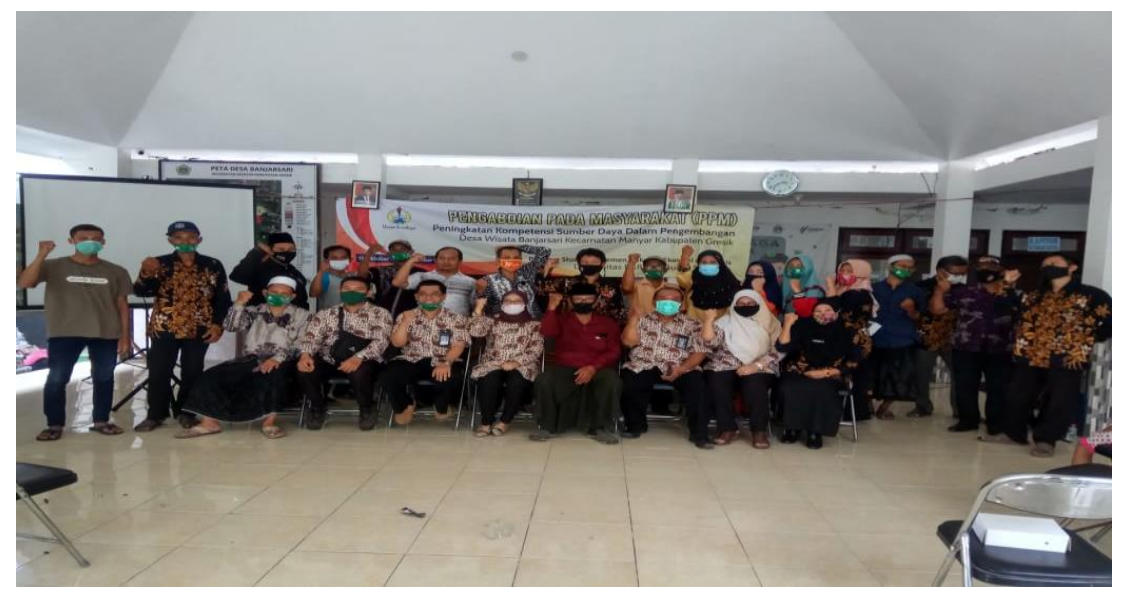

Gambar 1 


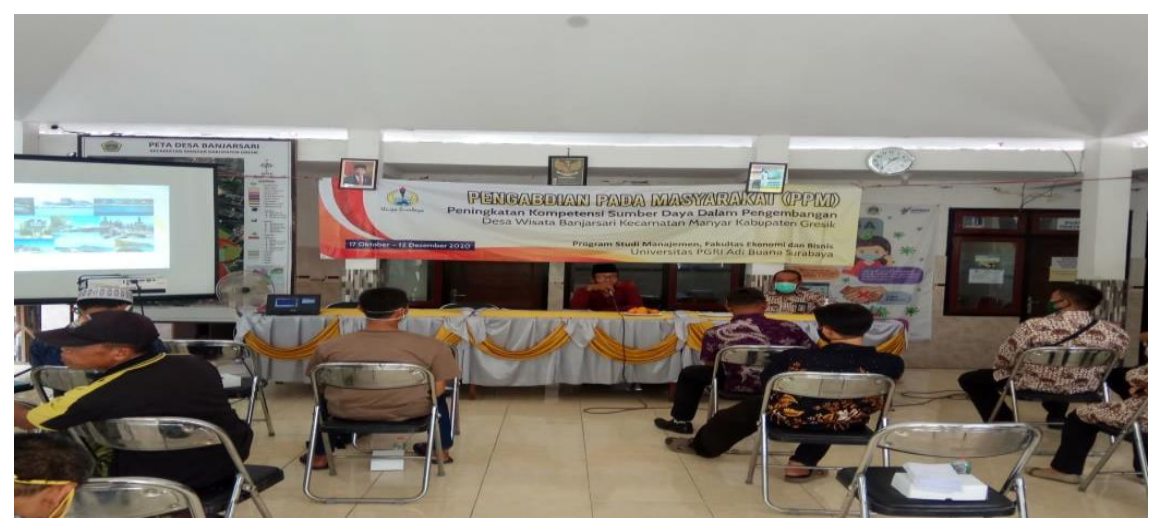

Gambar 2

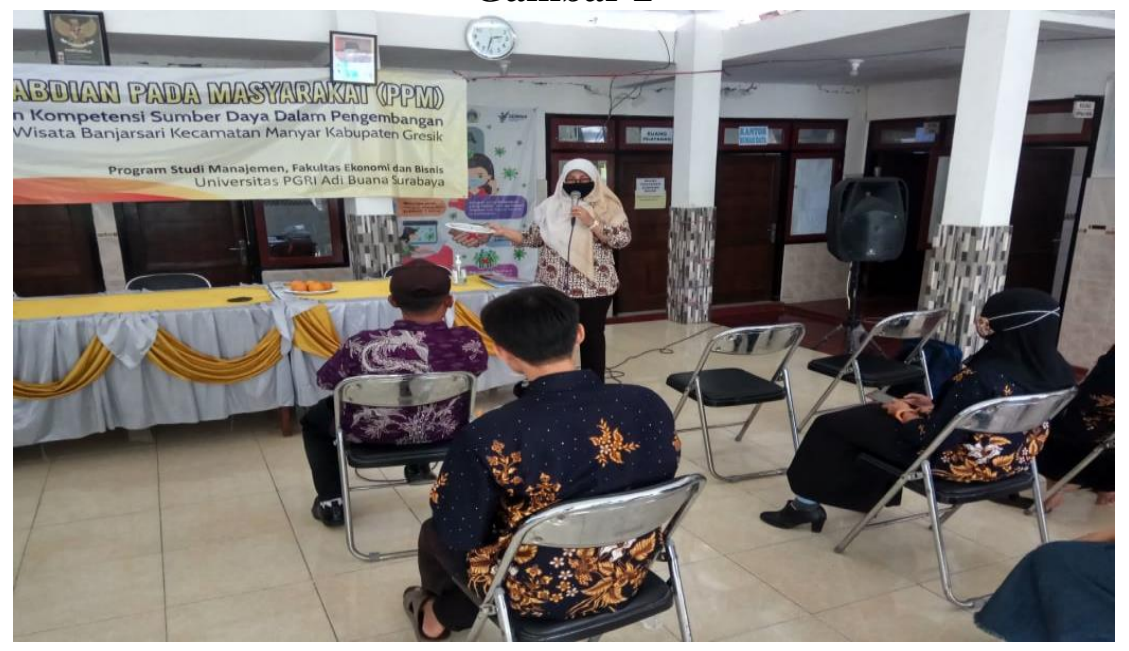

Gambar 3

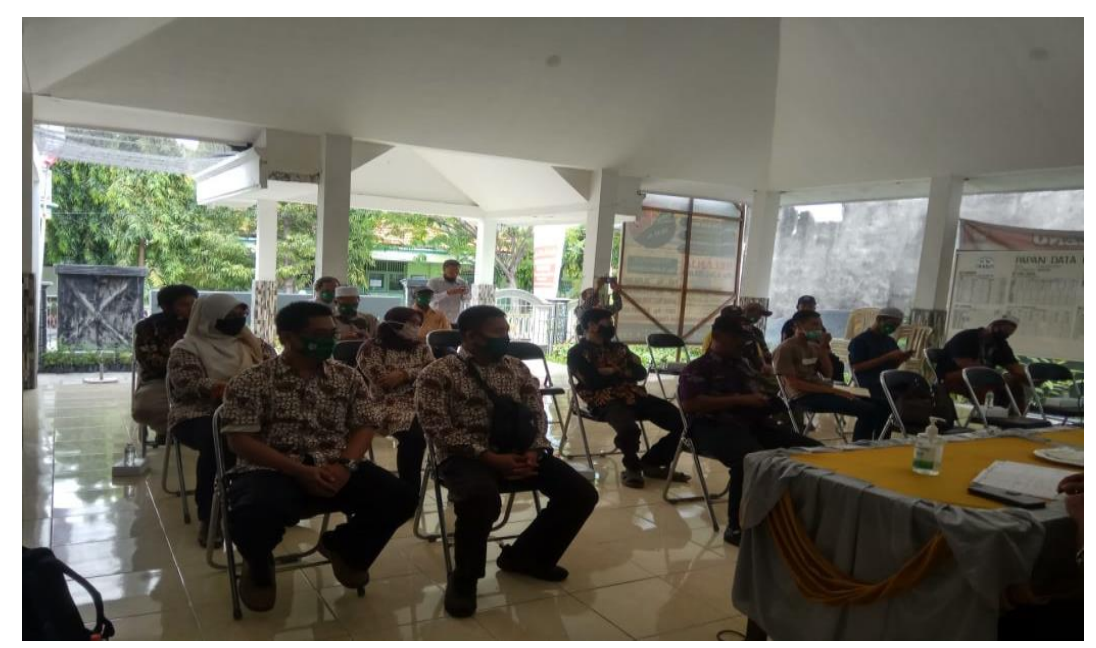

Gambar 4 


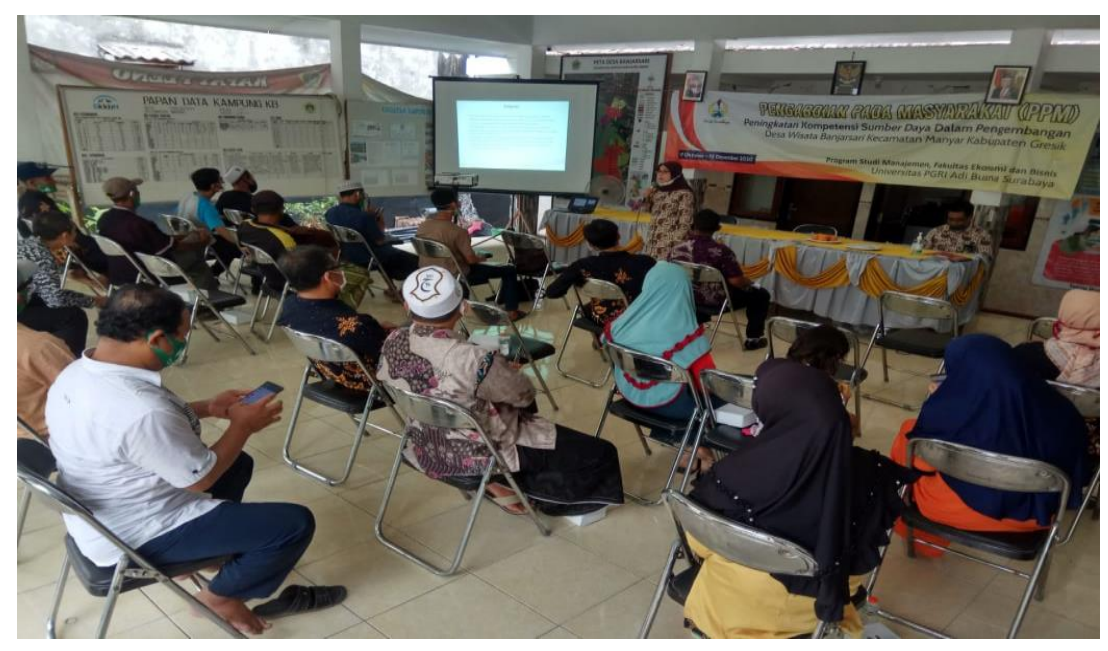

\section{Gambar 5}

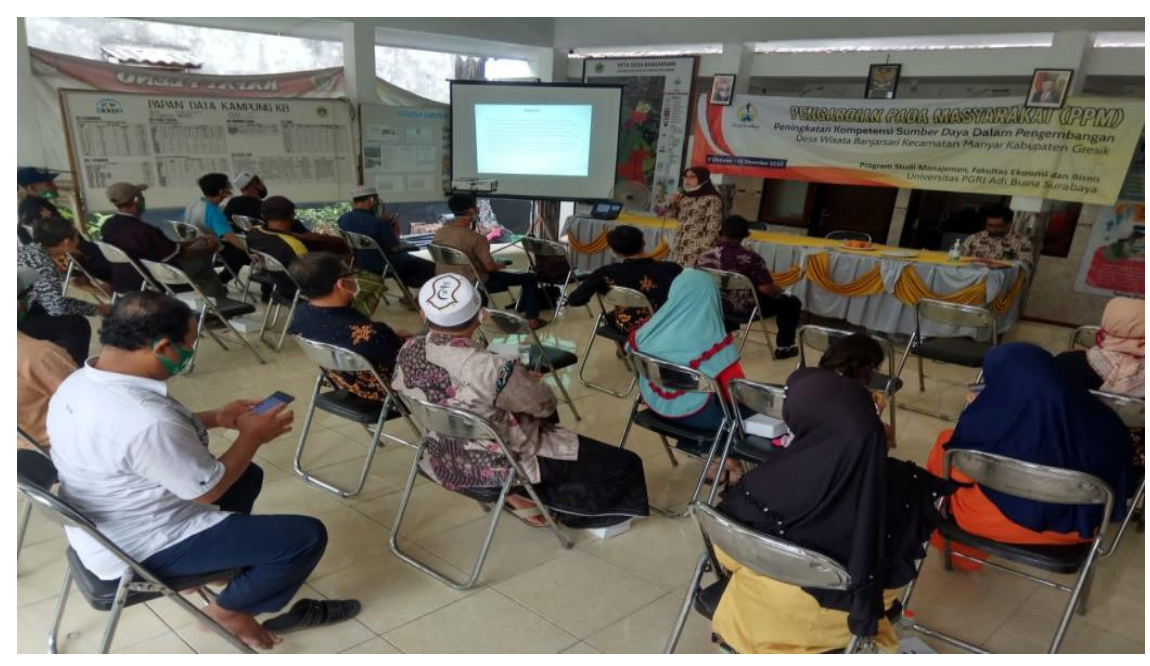

Gambar 6

\section{Contoh Desain Pariwisata}
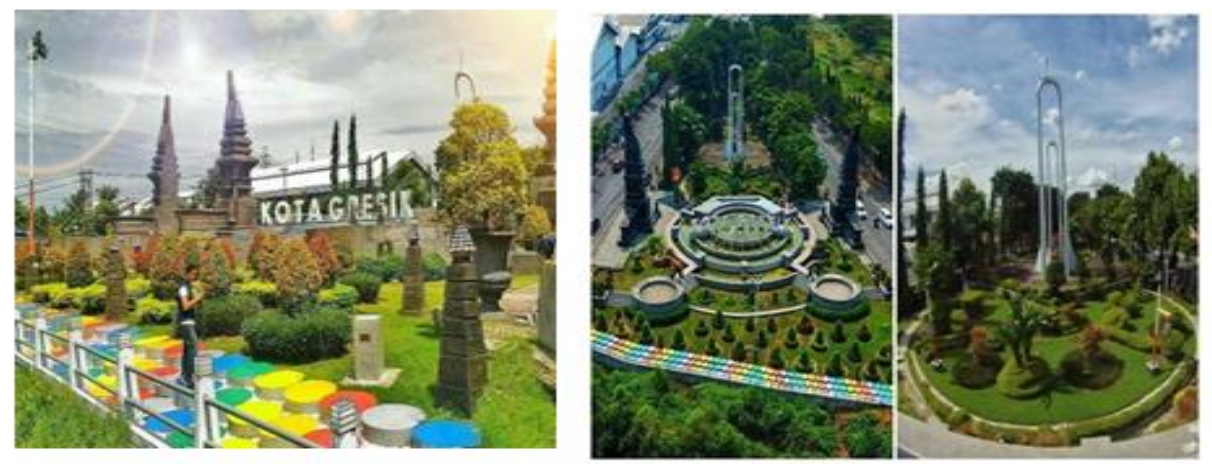

Gambar 7 


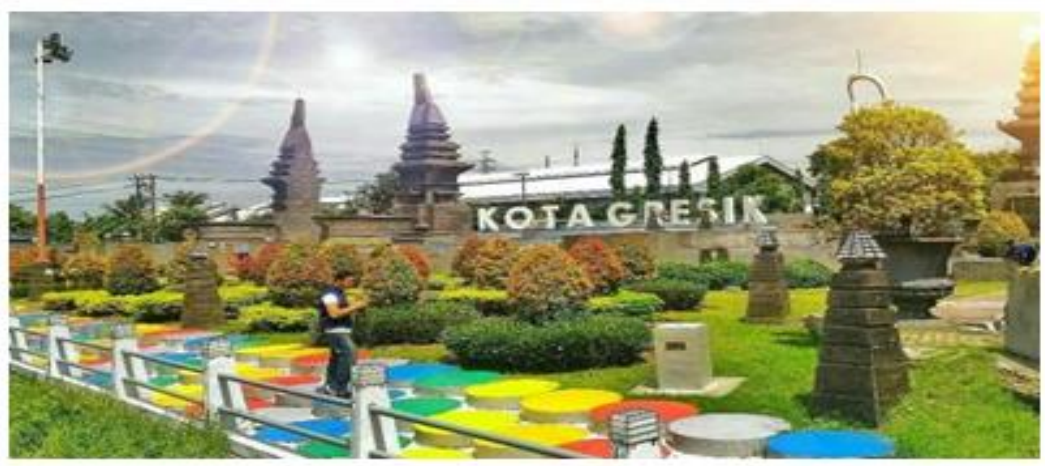

\section{Gambar 7}

\section{Tabel 0.1}

Contoh Rencana Anggaran Biaya kawasan Pariwisata Desa Banjarsari

\begin{tabular}{|c|c|c|c|c|c|c|}
\hline No & Uraian Kegiatan & Satuan & Volume & $\begin{array}{l}\text { Harga } \\
\text { Satuan (Rp) }\end{array}$ & $\begin{array}{l}\text { Jumlah } \\
\text { Harga }\end{array}$ & $\begin{array}{l}\text { Jumlah } \\
\text { Keseluruh } \\
\text { an }\end{array}$ \\
\hline 1. & Biaya Persiapan & & & & 10 Milyar & 10 Milyar \\
\hline \multirow[t]{2}{*}{2} & $\begin{array}{l}\text { Pekerjaaan } \\
\text { Persiapan } \\
\text { Pematangan Tanah }\end{array}$ & M3 & 30.000 & 90.000 & $\begin{array}{l}2.700 \\
\text { Milyar }\end{array}$ & \\
\hline & $\begin{array}{l}\text { Penahan tembok } \\
\text { Penggunaan Fasilitas } \\
\text { Jalan }\end{array}$ & M & 400 & 1.250 .000 & $\begin{array}{l}500 \text { juta } \\
7 \text { Milyat }\end{array}$ & \\
\hline
\end{tabular}


Tabel 0.2

Standar Belanja Sarana dan Prasarana

\begin{tabular}{|l|l|l|l|r|r|}
\hline No & Uraian Kegiatan & Satuan & Volume & $\begin{array}{c}\text { Harga } \\
\text { Satuan (Rp) }\end{array}$ & Jumlah Harga \\
\hline & Fasilitas Utama & & & & \\
\hline & Wisata Air & $\mathrm{m} 2$ & 300 & 2.500 .000 & 750.000 .000 \\
\hline & $\begin{array}{l}\text { Arena Wisata } \\
\text { Keluarga }\end{array}$ & $\mathrm{m} 2$ & 200 & 2.500 .000 & 500.000 .000 \\
\hline & Jogging Track & $\mathrm{m} 2$ & 150 & 3.000 .000 & 450.000 .000 \\
\hline & Area Pemancingan & $\mathrm{m} 2$ & 200 & 2.000 .000 & 400.000 .000 \\
\hline & Pondok Penginapan & $\mathrm{m} 2$ & 300 & 1.500 .000 & 450.000 .000 \\
\hline & Kantor Pengelola & $\mathrm{m} 2$ & 100 & 2.000 .000 & 200.000 .000 \\
\hline & Mushola & buah & 1 & 10.000 .000 & 10.000 .000 \\
\hline & Pujasera & $\mathrm{m} 2$ & 50 & 4.000 .000 & 200.000 .000 \\
\hline & Toilet & buah & 5 & 2.500 .000 & 12.500 .000 \\
\hline & Parkir & $\mathrm{m} 2$ & 50 & 1.000 .000 & 50.000 .000 \\
\hline & Jumlah & & & & 3.027 .000 .000 \\
\hline
\end{tabular}

\section{DAMPAK DAN MANFAAT KEGIATAN}

Dampak positif dalam kegiatan pengabdian pada masyarakat adalah wajib dilaksanakan karena mengikuti aturan dari Kemenriastekditi untuk mengembangkan kegiatan dosen untuk mencapai suatu capaian dan nilai yang tinggi. Selain melaksanakan Tri Dharma Perguruan Tinggi, maka perekembangan informasi dan komunikasi kepada masyarakat harus ditingkatkan supaya bisa mengikuti perkembangan teknologi. Oleh karean itu dampak negatifnya bagi dosen yang tidak mengikuti pengabdian pada masyarakat maka akan mendapatkan nilai yang rendah terutama ditingkat perguruan tinggi. Setiap kegiatan yang dilakukan akan membawa manfaat bagi masyarakat sekitar dan bagi perguruan tinggi. Pengabdian ini dilaksnakan oleh tim Program Studi Manajemen Fakultas Ekonomi dan bisnis Universitas PGRI Adi Buana Surabaya. Pelaksanaan pengabdian ini diharapkan membawa peningkatann bagi masyarakat desa Banjarsari Kecamatan Manyar Kabupaten Gresik dalam pengembangan desa wisata dalam mengelola keuangan sarana dan prasarana. Pihak pemerintah desa bisa bekerja sama dengan pemerintah daerah untuk mengembangkaan usahanya supaya perekonomian desa Banjarsari dan sekitarnya ada peningkatan dan mensejahterakatan masyarakat.

\section{SIMPULAN}

Hasil yang diharapkan dalam pelaksanaan pengabdian pada masyarakat adalah adanya pembuatan proposal dan perencanaan pengembangan desa wisata yang berada di desa Banjarsari Kecamatan Manyar Kabupaten Gresik segera terelaisasi oleh pemerintah daerah. Kepala Desa Banjarsari akan segera mengalokasikan anggaran yang sudah ada 
dan didukung oleh investor untuk memenuhi sarana dan prasarana. Pengabdian ini dilakukan dengan memberikan materi mengenai pentingnya membuat alokasi anggaran serta penggunaan sarana dan prasarana. Kegiatan pengabdian ini diikuti oleh kepala desa, perangkat desa, karang taruna, kinvestor dan masyarakat setempat. Usaha pengembangan wisata desa tersebut adalah cita-cita kepala desa dan masyarakat untuk meningkatkan perekonomian dan harapan sangat tinggi untuk mendapatkan keuntungan yang lebih dan untuk membangun desanya supaya tambah maju. Oleh karena itu masyarakat sangat antusias membantu kepala desanya supaya cita-cita tersebut bisa terwujud. Masyarakat desa selalu gotong royong membangun desanya supaya bisa maju dan menambah penghasilannya.

\section{UCAPAN TERIMA KASIH}

Alhamdulilah kami ucapkan dengan puji syukur kehadirat Allah SWT, kami Tim Pengabdian Pada Masyarakat dari Program Studi Manajemen Fakultas Ekonomi dan Bisnis Universitas PGRI Adi Buana Surabaya, mengucapkan terima kasih kepada kepala desa dan perangkat desa beserta masyarakat setempat yang telah menerima tim kami melaksanakan kegiatan pengabdian di desa Banjarsari Kecamatan Manyar Kabupaten Gresik. Kami telah menyelesaiakan tugas ini untuk mensosialisasikan materi yang telah tersampaikan. Semoga apa yang kami sampaikan bermanfaat bagi masyarakat desa Banjarsari serta menambah wawasan dan memberikaan semangat kepada kepala desa Banjarsari dan masyarakat yang akan membangun desa wisata dan memberikan motivasi kepada masyarakat dan sekitarnya.

\section{DAFTAR PUSTAKA}

Kabupaten Gresik Kecamatan Manyar, http://gwjsoft.com/gresik/profil_kec/index.php?kc=9 Akses 6 Agustus 2020 http://banjarsarimanyar.blogspot.com/2009/09/peta-banjarsari-manyar-gresik.html, akses 6 Agustus 2020

Desa Banjarsari Kecamatan Manyar, https://id.wikipedia.org/wiki/Banjarsari,_Manyar,_Gresik , akses 6 Agustus 2020 Pitana, I Gede dan Gayatri, Putu G. (2005), Sosiologi Patiwisata. Yogyakarta; Andi Janianton Damanik dkk (2019) Membangun Pariwisata Dari Bawah Penerbit dan Percetakan UGM Press Yogyakarta 